\title{
A Comparative Analysis of Profitability of Broiler Production Systems in Urban Areas of Edo State, Nigeria

\author{
${ }^{* 1}$ EMOKARO, CO; EWEKA KI
}

\author{
Department of Agricultural Economics and Extension Services, University of Benin, P.M.B.1154, Benin Nigeria \\ Correspondence author email: kayuze2000@yahoo.com
}

\begin{abstract}
This study investigated the cost implications of raising broilers under the battery cage and deep litter system of poultry production. The data used in the study were obtained from a cross-sectional survey of broiler farmers in Edo State from OctoberDecember, 2013. A multi-stage sampling process was used to select the 211 respondents for this study. The data collected were analyzed using descriptive statistics and profitability ratios. The study showed that the mean age of farmers that adopted the battery cage system was 48 years and 46 years for the farmers that used deep litter system. The Gross Margin analysis gave a value of $\$ 2,422.24$ and a Net Farm Income (NFI) of $\$ 2,412.40$ per bird for battery cage system while the deep litter system had a gross margin of $\$ 1,601.77$ and NFI of $\$ 1,593.80$ per bird. The profitability ratios showed Rate of Return on Investment (RRI) of about 92\%, Return on Labour (RL) of $\$ 18.03$, Return on Feed (RF)of 144.22 and Return Per Naira Invested (RNI) of $¥ 0.91$ for the battery cage system as against RRI (71\%), RL ( $\$ 30.28), \operatorname{RF}(\$ 117.95)$ and RNI ( $\$ 0.71)$ for the deep litter system. This shows that both systems were profitable and viable in the study area. It was therefore concluded that farmers should be enlightened on the relative profitability/viability of the battery cage system of broiler production over the deep litter system in the study area, as a guide to future investment in the enterprise. (C) JASEM

http://dx.doi.org/10.4314//jasem.v19i4.9
\end{abstract}

KEYWORDS: Battery cage, Cost, Deep litter, Net Farm Income, Viability

\section{INTRODUCTION}

The livestock industry is an important sub-sector of the agricultural sector of Nigeria's economy. According to Sani, Tahir and Kushwaha (2000), the role of this sector cannot be over-emphasized, considering the importance of animal protein in the diet of the people and the contribution from this sector to the Gross Domestic Product (GDP). In Nigeria, the production of food has not increased at the rate that can meet the demand from an increasing population. While food production increases at the rate of $2.5 \%$, food demand increases at a rate of more than $3.5 \%$ due to high rate of population growth of $2.83 \%$ (CBN, 2004). The apparent disparity between the rate of food production and demand for food in Nigeria has led to increasing resort to food importation and high rate of increase in food prices.

The demand and supply gap for animal protein intake is quite high and the Food Agriculture Organization (FAO, 2003) recommends that the minimum intake of protein by an average person should be 65 gm per day; of this, $36 \mathrm{gm}$ (i.e. 55.3\%) should come from animal sources. Nigeria is presently unable to meet this requirement. The animal protein consumption in
Nigeria is less than $8 \mathrm{gm}$ per person per day, which is a far cry from the FAO minimum recommendation (Niang and Jubin, 2001). As a result of the above, widespread hunger and malnutrition are evident in the country. Poultry products offer considerable potential for bridging the nutritional gap in view of the fact that high yielding exotic poultry are easily adaptable to our environment and the technology of production is relatively simple with returns on investment appreciably high.

The poultry industry has emerged as the most dynamic and fastest expanding segment in animal husbandry sector. Poultry eggs and meat contribution of the livestock share of the GDP increased from $26 \%$ in 1995 to $27 \%$ in 1999 (CBN, 1999). Despite these potentials the country still relies on imported frozen chicken to meet the domestic demand.

Durojaiye (2000) argued that luck alone does not explain the differences in the profitability levels of farms or ranches with the same resource endowment. Management is therefore a key factor determining the success or failure of a business enterprise; be it a firm or a farm. Therefore, poultry production like any 
other agricultural business activity requires that a farmer has a wealth of experience in the management of the enterprise. The farmer is out to make profit and in order to actualize this; he should be able to produce at a level that will make him recoup his cost, at the least.

Based on the above premise, this study was aimed at comparing the profitability of broiler production, under the common management systems (deep litter and battery cage) with a view to providing answers to pertinent questions on possible variations- in cost and other profitability indices affecting broiler production under the two systems. Therefore, the broad objective of the study was to carry out a comparative cost analysis of broiler production systems in the urban areas of Edo State. The specific objectives were to profile the socio-economic characteristics of the broiler farmers in the study area, identify the different systems and cost components of each system and evaluate the cost, returns and compare the profitability of the two systems of broiler production.

The null hypothesis and its alternative were formulated for this paper. $\mathrm{H}_{0}$ : There is no significant relationship between the profitability levels of broilers raised under battery cage and deep litter production systems.

$\mathrm{H}_{1}$ : There is significant relationship between the profitability levels of broilers raised under battery cage and deep litter production systems

\section{MATERIALS AND METHOD}

The study was conducted in Edo State of Nigeria. Edo State is located in the Southern rainforest region of the country. The State lies within the geographical coordinates of Latitudes $05^{\circ} 44^{\prime} \mathrm{N}$ and $07^{\circ} 34^{\prime} \mathrm{N}$ and Longitudes $06^{\circ} 04^{\prime} \mathrm{E}$ and $06^{\circ} 43^{\prime} \mathrm{E}$. Two distinct seasons are noticed in the State - the rainy season (March - September) and the dry season (October February). Relative humidity of the State is high; about $80-90 \%$ throughout the year. This climatic condition is favorable for poultry production (Emokaro and Eigbirhemonlen, 2012)

Edo State is made up of eighteen (18) Local Government Areas (LGAs) with a total landmass of $19,187 \mathrm{sq} \mathrm{km}$, and an estimated population of 3,926,587 million people using the projected annual growth rate of $2.7 \%$ (NPC, 2006). On the basis of Edo State Agricultural Development Programme (EADP) delineation, it is divided into three agroecological zones namely Edo South made up of seven LGAs, Edo Central made up of five LGAs and Edo North made up of six LGAs.
Sampling Technique and Sampling Size: A multi stage sampling technique was used in the selection of the respondents for the study in the State, two urban LGAs were purposively selected from each of the agro-ecological zones to give the study a State widefocus and a total of six LGAs (Ikpoba-okha, Oredo, Esan North-east, Esan South-west, Etsako central and Owan west) were selected. The second stage was a random selection of three communities each from the selected LGAs making a total of 18 communities. The last stage involved the selection of Fifteen (15) poultry farmers by snowballing from each of the communities to make a total of 270 respondents for the study.

Method of Data Collection: The primary data used in this study were gathered from a cross-section of the respondents via the use of a well-structured questionnaire

Method of Data Analysis: The data from the questionnaire were analyzed descriptively. frequency counts, means and percentages were used for the analysis of the socio economic information and the student t-test was used to test for the difference in the cost component of different production systems. The cost and returns were estimated with the use of budgetary technique and profitability/viability analysis. Three profitability/viability indicators, Gross margin (GM), Net Farm Income (NFI) and return per naira invested were estimated for the different production systems.

Gross Margin Analysis (GM): According to Odii (1998); Olukosi and Erhabor (2005), this measures the difference between the gross output or revenue and the variable cost of each enterprise in the farming system. It is given as: GM = TR - TVC.... (3) Where: $\mathrm{GM}=$ Gross Margin ( $\mathrm{TR}$, $=$ Total Revenue (N), TVC = Total Variable Costs ( $)$.

Net Farm Income (NFI): The net income or revenue of the farmers was computed as: $\mathrm{NI}=\mathrm{TR}-\mathrm{TC} \ldots$ (4) Where: NI $=$ Net Income $(1), T R=$ Total Revenue (N), TC = Total Cost (total variable cost + total fixed cost) Where: $T R=P_{y} y, \quad P_{y}=$ Price of the matured broiler, $\mathrm{y}=$ Total number of broilers sold TC will be computed as follows; $\mathrm{TC}=\mathrm{r}_{1} \mathrm{x}_{1}+\mathrm{r}_{2} \mathrm{x}_{2}+\mathrm{b} ; \mathrm{r}_{1} \mathrm{r}_{2}=$ prices of inputs (measured in Naira) $x_{1} \ldots . . x n=$ variable inputs (labour, feeds, drugs, electricity and operational costs measured in Naira) $b=$ cost of any fixed input (measured in Naira) Therefore NI = TR TC

Profitability Ratios: These are financial indices which show the performance of a business. The ratios 
as stated by Ayinde and Aromolaran (1998); Emokaro and Eigbirhemolen (2012) are as follows:

(i). Rate of Return on investment (RRI)

$\frac{\text { Net Income }}{\text { TC }} x 100 \%$.. (5); (ii). Return on Labour

$\underline{(\mathrm{RL}) ; R L}=\frac{\text { Total Revenue }}{\text { Labour in mand ays }}$ (6) (iii).Return on

feed $(\mathrm{RF}) ; \mathrm{RF} \quad=$ Total revenue Quantity of feed $(\mathrm{kg}) \ldots(7)$

\section{RESULTS AND DISCUSSION}

Socio-Economic Characteristics Broiler Farmers in the Study Area: Results presented in Table 1 show that $42 \%$ and $51 \%$ of farmers sampled were between the ages of 41-50 years of age for farmers practicing battery cage and deep litter system of broilers production respectively. About $29 \%$ of farmers that practice deep litter system were above 50 years of age. This implies that most of the farmers involved in these systems were still in the active labour age. This invariably affected the volume of production positively. Majority of the farmers in broiler production were males with $78 \%$ and $74 \%$ practicing the battery cage and deep litter systems respectively. This shows that broiler production was dominated by males in the study area. Almost all the farmers involved in broiler production under the two management systems had at least, secondary education. This must have influenced their choice of the management system. The average household sizes of the farmers were four and six for operators of battery cage and deep litter systems, respectively. Household size afforded the poultry farmers access to family labour, this could have positively affected the cost of labour.

Cost, Returns and Profitability Analysis of Broiler Production under the Two Systems: The mean estimates of cost and returns for broiler production under the two systems are presented in Tables 3 and 4. The total cost outlay of $\$ 216,829.50$, out of which \# 216,011.59 was incurred as total variable cost and \# 818.00 was estimated average depreciated fixed cost for an average of 86 birds for farmers who practiced the battery cage system while a total cost

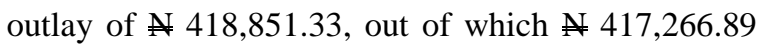
was incurred as total variable cost and 1,584.44 was estimated as average depreciated fixed cost for an average of 186 birds for operators of the deep litter system of broiler production. The total revenue from the sales of matured broiler for the battery cage system was $\$ 414,646.67$ as compared to 715 , 164.90 computed for operators of the deep litter system.

The Gross Margin (GM) analysis gave a value of 2, 422.24 and Net Farm Income (NFI) of $\$ 2,412.40$ per bird for battery cage system while the deep litter system had a GM of $\$ 1,601.77$ and NFI of 1 , 593.80 per bird. The profitability ratios showed Rate of Return on Investment of (RRI) of $91.69 \%$, Return on Labour of $\$ 18.03$ and Return on Feed of $\$$ 144.22 , for the battery cage system as compared to RRI of (70.74\%), RL of $\$ 30.28$ and RF of $\$ 117.95$ for the deep litter system. Although both systems of broiler production were profitable in the study area, the battery cage system gave a higher RRI of $91.69 \%$ which translates to 91 kobo for every 1 invested.

Feed conversion efficiency was higher in battery cage system than the deep litter system. This could be as a result of less feed wastage; however, the return on labour for the deep litter system generated higher returns per man-day as compared to battery cage suggesting that more labour is required in the deep litter system.

Distribution of farmers by system of poultry management; As shown in Table 2, 72\% of the respondents in the study area practiced the deep litter system while $28 \%$ of the respondents practiced battery cage system of broilers production. This implies that the deep litter system was more popular in the study area. 
Table 1: Socio-Economic Characteristics of Respondents

\begin{tabular}{|c|c|c|c|c|c|}
\hline & \multicolumn{2}{|c|}{ Battery cage } & \multicolumn{2}{|c|}{ Deep litter } \\
\hline & & Freq & $\%$ & Freq & $\%$ \\
\hline \multirow{5}{*}{ Age (years) } & $30 \&$ below & 1 & 1.7 & 3 & 2.0 \\
\hline & $31-40$ & 8 & 13.3 & 27 & 17.9 \\
\hline & $41-50$ & 25 & 41.7 & 77 & 51.0 \\
\hline & $>50$ & 26 & 43.3 & 44 & 29.1 \\
\hline & Total & 60 & 100.0 & 151 & 100.0 \\
\hline Mean & & 48 & & 46 & \\
\hline \multirow{3}{*}{ Marital status } & Single & 9 & 15.0 & 29 & 19.2 \\
\hline & Married & 51 & 85.0 & 122 & 80.8 \\
\hline & Total & 60 & 100.0 & 151 & 100.0 \\
\hline \multirow[b]{3}{*}{ Sex } & Female & 13 & 21.7 & 39 & 25.8 \\
\hline & Male & 47 & 78.3 & 112 & 74.2 \\
\hline & Total & 60 & 100.0 & 151 & 100.0 \\
\hline \multirow{4}{*}{$\begin{array}{l}\text { Family } \\
\text { (range) }\end{array}$} & $4 \&$ below & 15 & 25.0 & 74 & 49.0 \\
\hline & size $5-8$ & 39 & 65.0 & 71 & 47.0 \\
\hline & $9-12$ & 5 & 8.3 & 5 & 3.3 \\
\hline & Total & 60 & 100 & 151 & 100.0 \\
\hline
\end{tabular}

$\mathrm{m}$

\begin{tabular}{|c|c|c|c|c|c|}
\hline \multirow[t]{3}{*}{ Mean } & & 4 & & 6 & \\
\hline & $\begin{array}{l}\text { No forma } \\
\text { education }\end{array}$ & & & 3 & 2.0 \\
\hline & $\begin{array}{l}\text { primary } \\
\text { education }\end{array}$ & 2 & 3.3 & 2 & 1.3 \\
\hline \multirow[t]{4}{*}{ Educational level } & $\begin{array}{l}\text { secondary } \\
\text { education }\end{array}$ & 38 & 63.3 & 75 & 49.7 \\
\hline & $\begin{array}{l}\text { Tertiary } \\
\text { education }\end{array}$ & 20 & 33.3 & 71 & 47.0 \\
\hline & Total & 60 & 100.0 & 151 & 100.0 \\
\hline & $1-5$ & 20 & 33.3 & 57 & 37.7 \\
\hline \multirow{3}{*}{$\begin{array}{l}\text { Poultry farming } \\
\text { experience (range) }\end{array}$} & $6-10$ & 36 & 60.0 & 77 & 51.0 \\
\hline & $11-15$ & 4 & 6.7 & 17 & 11.3 \\
\hline & Total & 60 & 100.0 & 151 & 100.0 \\
\hline
\end{tabular}

Source; Field data, 2013

Table.2: Shows a Summary of the Production System Practiced in the Study Area

\begin{tabular}{lll}
\hline $\mathbf{6}$ & Frequency & $\%$ \\
\hline Battery cages & 60 & 28.44 \\
Deep litter system & 151 & 71.56 \\
Total & 211 & 100 \\
\hline
\end{tabular}

Source: Field data, 2013 
Table 3: Gross Margin Analysis

\begin{tabular}{|c|c|c|}
\hline & $\begin{array}{l}\text { Battery cage } \\
\text { (A) }\end{array}$ & $\begin{array}{l}\text { Deep litter } \\
\text { (A) }\end{array}$ \\
\hline $\begin{array}{l}\text { A. Total revenue } \\
\text { B. Variable cost items }\end{array}$ & $\begin{array}{l}\text { Mean } \\
414,646.67\end{array}$ & $\begin{array}{l}\text { Mean } \\
715,164.90\end{array}$ \\
\hline Drugs & $12,221.17$ & $21,666.23$ \\
\hline Electricity & $12,306.67$ & $13,619.87$ \\
\hline Feed cost & $149,400.00$ & $315,245.03$ \\
\hline Purchase cost & $19,094.86$ & $43,128.37$ \\
\hline Labour cost & $22,988.89$ & $23,607.39$ \\
\hline TVC & $216,011.59$ & $417,266.89$ \\
\hline C. Fixed cost & 818.00 & $1,584.44$ \\
\hline Total cost & $216,829.59$ & $418,851.33$ \\
\hline D. Gross Margin & $198,635.08$ & $297,898.01$ \\
\hline E. Net Income & $197,817.08$ & $296,313.57$ \\
\hline
\end{tabular}

Table 4.Profitability Ratios

\begin{tabular}{lll}
\hline & $\begin{array}{l}\text { Battery cage } \\
(\end{array}$ & $\begin{array}{l}\text { Deep litter } \\
\text { (n) }\end{array}$ \\
\hline Rate of Return on investment & 91.69 & 70.74 \\
Return on Labour & 18.03 & 30.28 \\
Return on Feed & 144.22 & 117.95 \\
\hline
\end{tabular}

Source: Field Data, 2013

Conclusion: From the study it was indicated that broiler farming is profitable for the battery cage and deep litter systems of production. However, the battery cage system offered relatively higher returns on investment in the study area. The system requires high degree of skill and knowledge in management as well as high capital investment in fixed inputs. It is recommended that farmers should constitute themselves in self-group to attract the required high capital investment from corporate financial institutions. Farmers should in addition compound their own feed as this will help to reduce the cost of feeds which accounted for over $70 \%$ of the total cost raising broiler from day old to point of sale.

\section{REFERENCES}

Ayinde, I.A. and Aromolaran, A.B. (1998). Economics of Rabbit in Abeokuta South Local Government Area of Ogun State.Nigerian Journal of Animal Production. 24(2):100-105

Central Bank of Nigeria, (1999).Annual Report and Statement of Accounts.CBN Publications.

Central Bank of Nigeria, (2004).Annual Report and Statement of Account.CBN Publications.

Durojaiye, B.O. (2000). Monitoring and Evaluation of Agricultural and Rural Development Project. Ademola Ige Ventures Ogun State, Nigeria.pp45-46

Emokaro, C.O. and Eigbirhemonlen, J.Y. (2012).Profitability Analysis of Poultry Egg Production in Esan and Ovia North-East Local
Government Areas of Edo State, Nigeria. International Journal of Agricultural and Development Economics. 2(2): 61 - 70.

Food and Agriculture Organizations (2003)."Food Security Concepts and Measurements". In Trade Reforms and Food Security: Conceptualizing the Linkages. Experts Consultative Forum held in Rome, Italy July $11-12$.

Murray,R.S and Larry J.S (2008). Schaums Outline of theory and Problems of Statistics 5th Edition. Mcgraw Hill Publisher pp. 244

Niang, T. and Jubrin, S. (2001).Quarterly Newsletter of the Nigeria Agriculture Question and Answer Service vol. 1 No 3.

NPC (2006).Population Census, (2006).Federal Republic of Nigeria .http://www.nigerianstatgov.ng/nationalbureauofstatist ics/officialgazette(fgp71/52007/2,500(124): pdf.

Odii, M.A. (1998). Modern Farm Management Technique.Alphabet Nigeria Publishers, Owerri, Nigeria.pp.24-26

Olukosi, J.O. and Erhabor, P.O. (2005).Introduction to Farm Management Economics Principles and Applications.Agitab Publishers Ltd. Zaria pp. 77 - 83.

Sani,R.M., Tahir,I. and Kushwaha,S. (2000).Economics of Poultry Production in Bauchi State: A Case Study of Bauchi Local Government Area. Nigeria Journal of Animal production, 27:109-113. 